\title{
RESIDUES OF SYNTHETIC HORMONES IN PORK, MADAGASCAR ${ }^{\ddagger}$
}

\author{
RÉSIDUS D'HORMONES DE SYNTHÈSE CHEZ LE PORC, MADAGASCAR
}

Residuos de hormonas sintéticas en CERdos, MADAGascar

\author{
V. Porphyre ${ }^{1 *}$ M. Rakotoharinome ${ }^{2}$ T. Randriamparany ${ }^{3}$ \\ D. Pognon ${ }^{1}$ S. Prévost ${ }^{4}$ B. Le Bizec ${ }^{4}$
}

Keywords: Swine - Pork - Animal growth promoter Kidney - Progestogen - Medroxyprogesterone - Madagascar.

Mots-clés : Porcin - Viande de porc - Promoteur de croissance animale - Rein - Progestagène - Médroxyprogestérone Madagascar.

Palabras clave: Cerdo - Carne de cerdo - Promotor del crecimiento animal - Riñón - Progestágeno Medroxiprogesterona - Madagascar.

In Madagascar, little information is available on drug residues in animal products. Official veterinary services have been recently informed about the misuse of human injectable contraceptives in pig farms. Farmers and local animal health workers have been suspected of treating pigs for growth promotion and of using human progestins, especially medroxyprogesterone acetate (MPA), as a chemical alternative method for castration of sows that are then fattened before culling. Indeed, MPA may arrest the onset of farrowing and induce post-lactational anestrus in sows.

Because the use of synthetic hormones in pig husbandry is considered a fraud by the Malagasy legislation, an exploratory study was carried out to confirm these suspicions and investigate the main molecules concerned.

We investigated 80 pigs slaughtered in seven Malagasy abattoirs and raised in eight (out of 22) Malagasy regions (i) to confirm the contamination of carcasses by anabolic hormones by liquid chromatography coupled to mass spectrometry (LC-MS/MS), (ii) to identify the concerned molecules, and (iii) to explore consumers' exposure to hormone residues. Only adult sows were sampled considering that chemical castration with progestogens was the most common hypothesis of misuse of synthetic hormones in the field.

The screening of the 80 kidney-fat samples did not reveal residues of progestogens other than MPA. MPA-positive samples were detected in 10 out of 15 districts $(66.7 \%)$, and in all eight

1. Cirad, UMR Selmet, station de Ligne-Paradis, 7 chemin de l'IRAT, 97410 Saint-Pierre, Réunion, France.

2. Services vétérinaires de Madagascar, ministère de l'Elevage, rue Farafaty Ampandrianomby, Antananarivo, Madagascar.

3. Laboratoire national de diagnostic vétérinaire, ministère de l'Elevage, Antananarivo 102, Madagascar.

4. Laberca - Oniris, route de Gachet, CS 50707, 44307 Nantes, France.

* Corresponding author

E-mail: vincent.porphyre@cirad.fr

This text summarizes an oral communication presented at QualiREG Scientific Days in 2012. Since then, full results have been published as a research article (Porphyre et al., 2014).

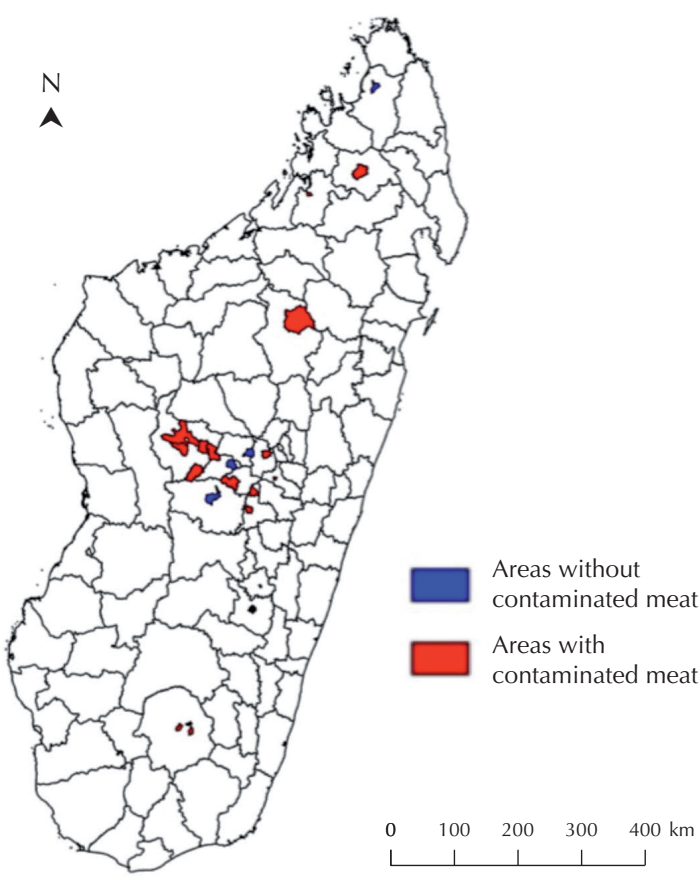

Figure 1: Location in the studied areas (i.e. in 8 of a total of 22 regions) where hormone residues were detected in kidney fat in culled sows $(n=80)$ in Madagascar in 2010.

surveyed regions except one (87.5\%), Diana Region in Northern Madagascar. Our results revealed heavy contamination of pork products by synthetic hormone residues; its prevalence was high considering that such residues are not supposed to occur according to the Malagasy legislation. Investigations by Malagasy veterinary services revealed that farmers and animal health workers purchased syringes of progestogens (Confiance ${ }^{\mathrm{TM}}$, Pfizer). These low-price progestins are easily available in private local dispensaries and basic health centers (public sector).

Without any control, farmers can easily administer MPA to pigs. It has thus become urgent to launch public-awareness campaigns and improve control within the sectors of animal production and public health over the entire country.

\section{REFERENCES}

1. PORPHYRE V., RAKOTOHARINOME M., POGNON D., RANDRIAMPARANY T., PREVOST S., LE BIZEC B., 2013. Residues of medroxyprogesterone acetate detected in sows at slaughterhouse, Madagascar. Food Addit. Contam. Part A, 30: 2108-2113 DOI: 10.1080/19440049.2013.848293.

Accepted 30 April 2015; Online publication June 2015 